\title{
SISTEM PENDUKUNG KEPUTUSAN PENGAJUAN KREDIT MENGGUNAKAN METODE WEIGHTED PRODUCT (WP) DI PRIORITAS GROUP PURWAKARTA
}

\author{
Dede Irmayanti ${ }^{1}$, Mochzen Gito Resmi ${ }^{2}$, Indana Zulfa Nazmu Fadhilah ${ }^{3}$ \\ 1,2,3 Teknik Informatika, Sekolah Tinggi Teknologi Wastukancana \\ ${ }^{1}$ dedeirmayanti@ stt-wastukancana.ac.id, ${ }^{2}$ mochzen@stt-wastukancana.ac.id, ${ }^{3}$ indanazulfa399@gmail.com
}

\begin{abstract}
Abstrak
Kredit adalah kepercayaan bahwa seseorang atau penerima kredit akan memenuhi segala sesuatu yang telah diperjanjikan terlebih dahulu pada masa yang akan datang. Prioritas Group merupakan perusahaan leasing yang memberikan jasa kredit barang elektronik dan furnitur bagi pemohon kredit dan mengambil keuntungan dari pembayaran bunga kredit. Satu kendala yang menyebebkan pendapatan perusahaan berkurang adalah kredit macet, untuk itu maka diperlukan penyeleksian calon konsumen yang dilakukan oleh kredit analis, karena kasus yang sering terjadi adalah konsumen yang mendaftar karna kondisi ekonomi yang tidak sesuai. Sehubungan dengan perihal diatas, bahwa kasus kredit macet yang menyebabkan berkurangnya profit perusahaan leasing dapat diminimalisir tergantung kinerja dari kredit analis dalam proses menentukan calon konsumen. Pada penelitian ini bertujuan untuk merancang dan membangun sebuah sistem pendukung keputusan dengan metode Weighted Product (WP) dan metode pengembangan prototype, perancangan dilakukan dengan Unified Modeling Language (UML) serta pengkodean program menggunakan $p h p$ dan database dengan menggunakan mysql, upaya untuk membantu kredit analis di Prioritas Group Purwakarta dalam menetukan calon konsumen yang sesuai dengan standar perusahaan. Maka dengan adanya sistem ini dapat membantu team kredit analis dalam memberikan alternatif keputusan dalam memilih calon konsumen dilengkapi nilai dengan mengacu kepada kriteria-kriteria pengambilan keputusan yang telah ditetapkan oleh perusahaan dalam memilih konsumen untuk meningkatkan kualitas penilaian dan keputusan yang diambil.
\end{abstract}

Kata kunci : sistem pendukung keputusan, weighted product, kredit, prototype, UML

\section{Pendahuluan}

Perkembangan teknologi yang begitu cepat saat ini merupakan sebuah tantangan sendiri bagi perusahaan. Disamping itu perusahaan mendapatkan keuntungan yang begitu banyak apabila dapat memanfaatkannya dengan baik. Prioritas Group merupakan perusahaan pembiayaan konsumen (consumers finance company) yang melakukan pembiayaan pengadaan barang untuk kebutuhan konsumen dengan sistem pembayaran angsuran secara berkala. Perusahaan ini telah menetapkan standar untuk menerima atau menolak resiko kredit, yaitu menentukan siapa yang berhak menerima kredit yang telah memenuhi syarat 5C, bagaimana karakter konsumen(Character), kapasitas melunasi kredit (Capacity), pendapatan atau penghasilan yang dimiliki konsumen (Capital), jaminan yang dimiliki konsumen (Collateral) dan kondisi fisik konsumen (Condition) yang semua ini menjadi kriteria penentu dalam pengambilan keputusan.

Perusahaan harus bisa cermat dalam memilih para calon konsumen dikarenakan dengan sistem kredit ini perusahaan mempunyai piutang sehingga dalam pemilihan calon konsumen harus dilakukan secara teliti agar tidak terjadi kesulitan dalam pembayaran angsuran. Apalagi penilaian kelayakan kredit yang dilakukan masih menggunakan cara manual dengan database yang digunakan masih dengan Microsoft Excel sehingga membutuhkan waktu yang lama untuk pengolahan data.

Satu kendala yang menyebabkan pendapatan perusahaan berkurang adalah kredit macet, dimana tercatat 8,43\% dari 2689 konsumen di bulan Maret 2020. Kredit macet adalah keadaan dimana konsumen kredit sudah tidak sanggup membayar, hilang jejak atau barang sudah pindah tangan. Dalam kasus seperti ini, apabila kredit-kredit yang telah disalurkan banyak yang macet maka akan menimbulkan tunggakan. Tunggakan ini dapat menghambat laju perusahaan dan mengganggu kegiatan operasional lain, sehingga perlu dilakukan seleksi yang didasarkan pada analisis data pemohon kredit. Pada umumnya perusahaan memiliki tenaga kerja dibagian kredit analis untuk melakukan analisa terhadap kemampuan membayar calon konsumen dan survey lapangan. Banyaknya pemohon kredit yang mengajukan kredit dengan kondisi yang berbeda-beda menuntut kejelian kredit analis dalam pengambilan keputusan.

Kasus kredit macet yang menyebabkan berkurangnya profit perusahaan leasing dapat diminimalisir tergantung dari kinerja kredit analis dalam proses menentukan konsumen kredit. 
Sehingga seorang kredit analis dituntut untuk bekerja cepat dan teliti dalam menganalisa banyaknya data calon konsumen yang masuk sehingga tidak menutup kemungkinan terjadi human error, seperti kesalahan perhitungan, salah membaca data dan lain-lain. Oleh karana itu, dalam upaya membantu kredit analis dalam kegiatan pengambilan keputusan konsumen layak kredit, diperlukan sebuah model sistem pendukung keputusan berbasis web yang dapat memberikan kemudahan dalam melakukan analisa data, serta membantu pengolahan data konsumen kredit menjadi informasi untuk mengambil keputusan dari masalah semi terstruktur.

Sistem Pendukung Keputusan (SPK) merupakan salah satu solusi perusahaan yang membantu melakukan pengambilan keputusan kelayakan kredit. Sistem pendukung keputusan memanfaatkan data, model, serta memberikan antarmuka pengguna yang mudah dan dapat menggabungkan pemikiran dalam pengambilan keputusan. Untuk merancang suatu sistem pendukung keputusan, dibutuhkan suatu metode perhitungan yang digunakan untuk menyelesaikan permasalahan dengan multi-kriteria. Salah satu metode perhitungan yang digunakan adalah Weighted Product (WP). Metode Weighted Product (WP) digunakan dalam penelitian ini untuk menentukan calon konsumen mana yang layak untuk diberikan kredit.

\section{Kajian Pustaka}

\subsection{Sistem Pendukung Keputusan}

Sistem pendukung keputusan adalah proses pengambilan keputusan dibantu menggunakan komputer untuk membantu pengambilan keputusan dengan menggunakan beberapa data dan model tertentu untuk menyelesaikan beberapa masalaha yang tidak terstruktur (Kusumadewi, purnomo, 2010).

Keberadaan SPK pada perusahaan atau organisasi bukan untuk menggantikan tugas-tugas pengambil keputusan, tetapi merupakan sarana yang membantu bagi mereka dalam pengambilan keputusan. Dengan menggunakan data-data yang diolah menjadi informasi untuk mengambil keputusan dari masalah-masalah semi-terstruktur. Dalam implementasi SPK, hasil dari keputusankeputusan dari sistem bukanlah hal yang menjadi patokan, pengambilan keputusan tetap berada pada pengambil keputusan. Sistem hanya menghasilkan keluaran yang mengkalkulasi data-data sebagaimana pertimbangan seorang pengambil keputusan. Sehingga kerja pengambil keputusan dalam mempertimbangkan keputusan dapat dimudahkan (Wibowo, 2011).

\subsection{Metode Weighted Product (WP)}

Metode wighted product merupakan bagian dari konsep Multi Criteria Decision Making
(MCDM) yang merupakan teknik pengambilan keputusan dari beberapa pilihan alternative yang ada (Sari, 2017).

Metode WP menggunakan perkalian untuk menghubungkan rating atribut, dimana rating setiap atribut harus dipangkatkan dulu dengan bobot atribut yang bersangkutan (Jalil, dkk, 2017).

Preferensi atau alternative $A i$ diberikan oleh persamaan $1:$.

$$
S_{i}=\prod_{J=1}^{n} X_{i j} w_{j}
$$

Keterangan :

$S$ : Preferensi alternatif dianalogikan sebagai vector s $x_{i j}$ : Nilai variabel dari alternative pada setiap atribut $w_{j}$ : Nilai bobot kriteria

$n$ : Banyaknya kriteria

$i$ : Nilai alternative

$j$ : Nilai kriteria

Dengan $i=1,2, \ldots \mathrm{m}$; dimana $\sum \mathrm{Wj}=1, \mathrm{Wj}$ adalah pangkat bernilai positif untuk atribut keuntungan dan bernilai negative untuk atribut biaya oleh persamaan 2 .

$$
\mathrm{W}_{\mathrm{j}}=\frac{\mathrm{W}_{\mathrm{J}}}{\sum \mathrm{W}_{\mathrm{J}}}
$$

Preferensi relatif dari setiap alternatif, diberikan oleh persamaan 3 .

$$
V_{i} \frac{\prod_{j=1}^{n}\left(x_{i j}\right)^{w_{j}}}{\prod_{j=1}^{n}\left(x_{j} *\right)^{w_{j}}}
$$

Keterangan :

$V$ : Preferensi relatif dari setiap alternatif dianalogikan sebagai vector $V$

$X_{i j}$ : Nilai Variabel dari alternatif pada setiap atribut

$W_{j}$ : Nilai bobot kriteria

$n$ : Banyaknya kriteria

$i$ : Nilai alternatif

$j$ : Nilai kriteria

*: Banyaknya kriteria yang telah dinilai pada veltor $\mathrm{S}$

\section{Metode Penelitian}

Model yang digunakan pada penelitian ini adalah Model Prototype yang digambarkan sebagai siklus lingkaran yang tidak berujung, sehingga bila pada fase deployment, delivery \& feedback ditemukan adanya ketidaksesuaian atau fungsifungsi yang tidak berjalan, maka proses pengembangan dapat kembali ke fase pertama untuk menganalisa berbagai kekurangan yang ada. Model pengembangan Prototype dapat dilihat pada gambar 1. 


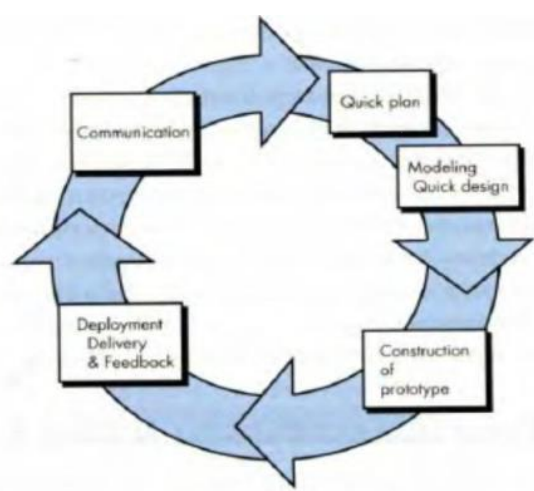

Gambar 1 Model Prototype (Pressman, 2010)

\section{Hasil dan pembahasan}

\subsection{Communication}

Pada tahap ini, penulis melakukan diskusi dengan kredit analis di kantor Prioritas Group untuk mendapatkan informasi mengenai syarat pengajuan kelayakan kredit. Kemudian, hasil dari diskusi dijadikan sebuah deskripsi permasalahan. Sehingga diperoleh gambaran terkait sistem pengambil keputusan yang diinginkan sebagai solusi. Alur prose penilaian kelayaka kredit yang sedang berjalan dapat dilihat pad agambar 2 .

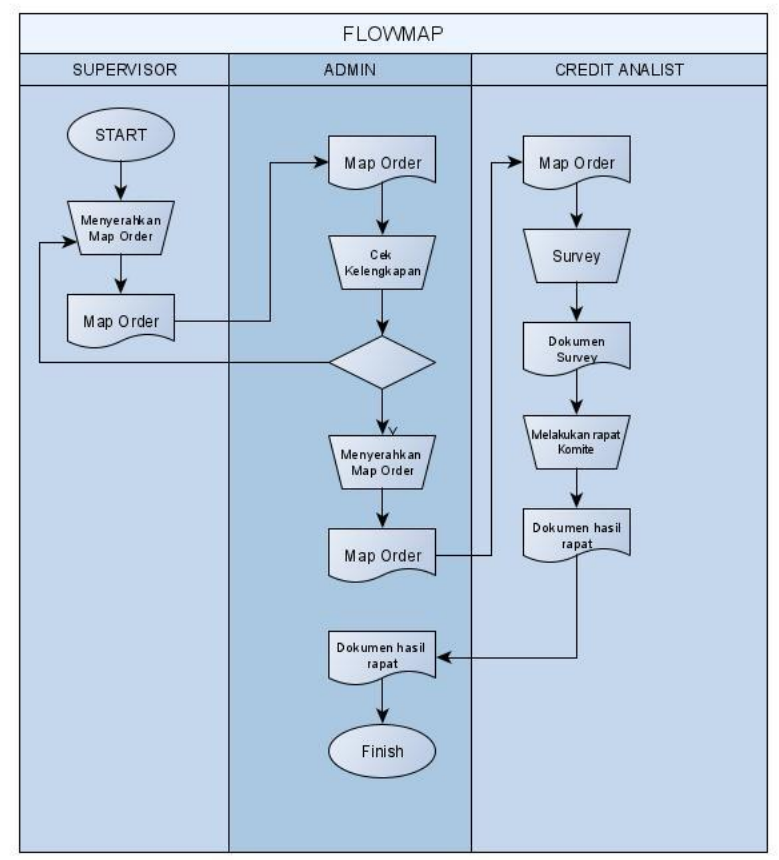

Gambar 2 FLowmap Sistem Berjalan

Setelah diketahui alur sistem berjalan, selanjutnya dilakukan analisis terhadap sistem yang diusulkan. Alur sistem usulan peniaian kelayakan kredit dapat dilihat pada gambar 3 .

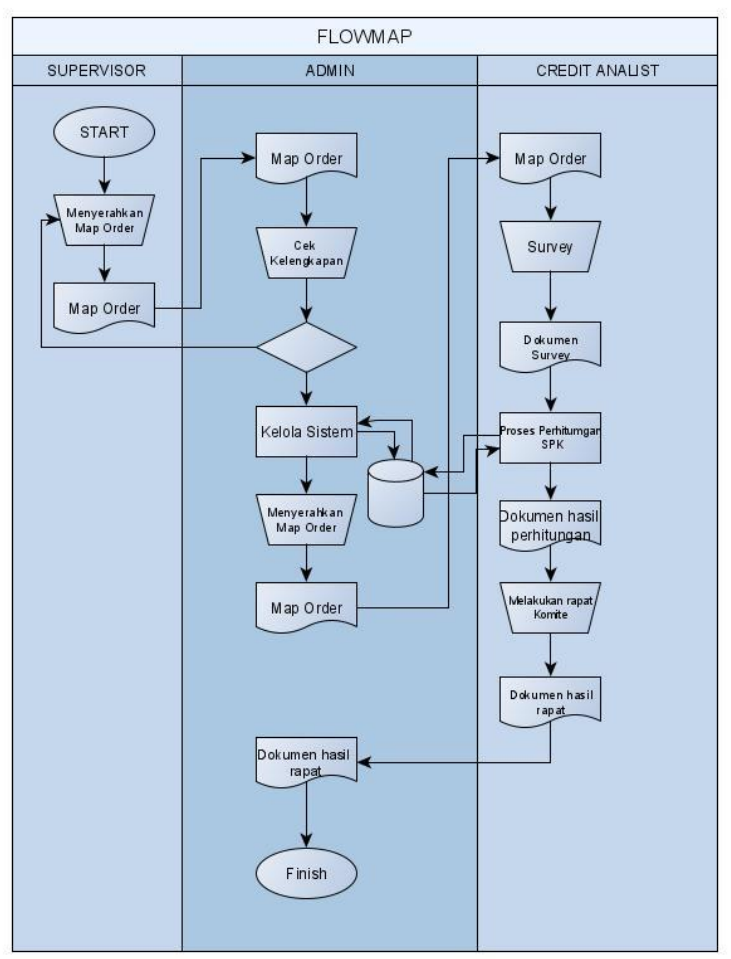

Gambar 3 Flowmap Sistem Usulan

Langkah-langkah pemecahan masalah dengan menggunakan Algoritma WP adalah sebagai berikut :

1. Menentukan kriteria-kriteria yang akan dijadikan acuan dalam pengambilan keputusan. Jenis-jenis kriteria penilaian dapat dilihat pada tabel 1 .

\begin{tabular}{|c|c|c|}
\hline \multicolumn{3}{|c|}{ Tabel 1 Kriteria } \\
\hline No & Kriteria & Sub Kriteria \\
\hline \multirow{2}{*}{1} & \multirow{2}{*}{ Character } & Baik \\
\hline & & Buruk \\
\hline \multirow{5}{*}{2} & \multirow{5}{*}{ Capital } & $<1,5-\leq 2 \mathrm{JT}$ \\
\hline & & $2-\leq 3 \mathrm{JT}$ \\
\hline & & $3-\leq 4 \mathrm{JT}$ \\
\hline & & $4-\leq 5 \mathrm{JT}$ \\
\hline & & $\geq 5 \mathrm{JT}$ \\
\hline \multirow{2}{*}{3} & \multirow{2}{*}{ Capacity } & Ada \\
\hline & & Tidak Ada \\
\hline \multirow{2}{*}{4} & \multirow{2}{*}{ Collateral } & Elektronik \\
\hline & & Furniture \\
\hline \multirow{2}{*}{5} & \multirow{2}{*}{ Condition } & Tidak Cacat \\
\hline & & Cacat \\
\hline
\end{tabular}

Selanjutnya dibuat nilai pada masing-maisng sub kriteria penilaian. Nilai sub kriteria dapat dilihat pada table 2 . 
Tabel 2 Nilai Kriteria

\begin{tabular}{|c|c|c|c|}
\hline No & Kriteria & Sub Kriteria & Nilai \\
\hline \multirow{2}{*}{1} & \multirow{2}{*}{ Character } & Baik & 90 \\
\hline & & Buruk & 70 \\
\hline \multirow{5}{*}{2} & \multirow{5}{*}{ Capital } & $<1,5 \mathrm{JT}$ & 60 \\
\hline & & $2 \mathrm{JT}$ & 70 \\
\hline & & $3 \mathrm{JT}$ & 80 \\
\hline & & $4 \mathrm{JT}$ & 90 \\
\hline & & $>4,5 \mathrm{JT}$ & 100 \\
\hline \multirow{2}{*}{3} & \multirow{2}{*}{ Capacity } & Ada & 90 \\
\hline & & Tidak Ada & 70 \\
\hline \multirow{2}{*}{4} & \multirow{2}{*}{ Collateral } & Elektronik & 80 \\
\hline & & Furniture & 70 \\
\hline \multirow{2}{*}{5} & \multirow{2}{*}{ Condition } & Tidak Cacat & 90 \\
\hline & & Cacat & 70 \\
\hline
\end{tabular}

2. Setelah kriteria dan sub kriteria ditentukan selanjutnya menentukan bobot nilai dan bobot preferensi untuk setiap kriteria. Nilai bobot kriteria dapat dilihat pada tabel 3 .

\begin{tabular}{|l|c|}
\hline \multicolumn{1}{|c|}{ Tabel 3 Bobot nilai kriteria } \\
\hline Sangat Penting & 5 \\
\hline Penting & 4 \\
\hline Cukup Penting & 3 \\
\hline Kurang Penting & 2 \\
\hline Tidak Penting & 1 \\
\hline
\end{tabular}
table 4.

Sedangkan bobot preferensi dapat dilihat pada

Tabel 4 Bobot Preferensi Setiap Kriteria

\begin{tabular}{|l|l|c|}
\hline \multicolumn{2}{|c|}{ Kriteria } & Bobot (W) \\
\hline C1 & Character & 5 \\
\hline C2 & Capital & 5 \\
\hline C3 & Capacity & 5 \\
\hline C4 & Collateral & 4 \\
\hline C5 & Condition & 5 \\
\hline
\end{tabular}

3. Selanjutnya dilakukan proses menentukan rating kecocokan dari setiap alternatif pada setiap kriteria seperti yang terlihat pada tabel 5 .

Tabel 5 Tabel Rating Kecocokan Alternatif

\begin{tabular}{|l|c|c|c|c|c|}
\hline \multicolumn{1}{|c|}{ Nama } & C1 & C2 & C3 & C4 & C5 \\
\hline Elin & Baik & 2 Jt & $\begin{array}{l}\text { Tidak } \\
\text { Ada }\end{array}$ & $\begin{array}{l}\text { Elektr } \\
\text { onik }\end{array}$ & $\begin{array}{l}\text { Tidak } \\
\text { Cacat }\end{array}$ \\
\hline Esti & Buruk & 2 Jt & Ada & Furnit & Tidak \\
\hline
\end{tabular}

\begin{tabular}{|l|l|l|l|l|l|}
\hline \multicolumn{1}{|c|}{ Nama } & $\mathrm{C} 1$ & $\mathrm{C} 2$ & $\mathrm{C} 3$ & $\mathrm{C} 4$ & $\mathrm{C} 5$ \\
\hline $\begin{array}{l}\text { Marisa } \\
\text { Devi }\end{array}$ & & & & ure & Cacat \\
\hline $\begin{array}{l}\text { Aan } \\
\text { Aminah }\end{array}$ & Buruk & $4 \mathrm{Jt}$ & $\begin{array}{l}\text { Tidak } \\
\text { Ada }\end{array}$ & $\begin{array}{l}\text { Furnit } \\
\text { ure }\end{array}$ & $\begin{array}{l}\text { Tidak } \\
\text { Cacat }\end{array}$ \\
\hline $\begin{array}{l}\text { Erna } \\
\text { Hermaw } \\
\text { ati }\end{array}$ & Baik & $\begin{array}{l}< \\
1.5\end{array}$ & $\begin{array}{l}\text { Tidak } \\
\text { Ada }\end{array}$ & $\begin{array}{l}\text { Furnit } \\
\text { ure }\end{array}$ & $\begin{array}{l}\text { Tidak } \\
\text { Cacat }\end{array}$ \\
\hline $\begin{array}{l}\text { Yani } \\
\text { Suryani }\end{array}$ & Buruk & $\begin{array}{l}> \\
4.5 \\
\mathrm{Jt}\end{array}$ & Ada & $\begin{array}{l}\text { Elektr } \\
\text { onik }\end{array}$ & $\begin{array}{l}\text { Tidak } \\
\text { Cacat }\end{array}$ \\
\hline $\begin{array}{l}\text { Abdul } \\
\text { Aziz } \\
\text { maulana }\end{array}$ & Baik & $3 \mathrm{Jt}$ & $\begin{array}{l}\text { Tidak } \\
\text { Ada }\end{array}$ & $\begin{array}{l}\text { Elektr } \\
\text { onik }\end{array}$ & $\begin{array}{l}\text { Tidak } \\
\text { Cacat }\end{array}$ \\
\hline $\begin{array}{l}\text { Iis Siti } \\
\text { Hoiriyah }\end{array}$ & Baik & $2 \mathrm{Jt}$ & Ada & $\begin{array}{l}\text { Elektr } \\
\text { onik }\end{array}$ & Cacat \\
\hline $\begin{array}{l}\text { Nunung } \\
\text { Nur } \\
\text { Azizah }\end{array}$ & Baik & $4 \mathrm{Jt}$ & Ada & $\begin{array}{l}\text { Elektr } \\
\text { onik }\end{array}$ & $\begin{array}{l}\text { Tidak } \\
\text { Cacat }\end{array}$ \\
\hline $\begin{array}{l}\text { Muham } \\
\text { mad } \\
\text { Dahlan }\end{array}$ & Baik & $\begin{array}{l}> \\
4.5\end{array}$ & Ada & $\begin{array}{l}\text { Elektr } \\
\text { onik }\end{array}$ & $\begin{array}{l}\text { Tidak } \\
\text { Cacat }\end{array}$ \\
\hline $\begin{array}{l}\text { Nani } \\
\text { Heryani } \\
\text { Jani }\end{array}$ & Baik & $\begin{array}{l}\text { Tidak } \\
\text { Ada }\end{array}$ & $\begin{array}{l}\text { Furnit } \\
\text { ure }\end{array}$ & $\begin{array}{l}\text { Tidak } \\
\text { Cacat }\end{array}$ \\
\hline
\end{tabular}

Tahap selanjutnya dilakukan perbaikan bobot terlebih dahulu dengan menggunakan persamaan 2 dengan bobot awal $\mathrm{W}=(5,5,5,4,5)$.

$$
\begin{aligned}
& W C 1=\frac{5}{5+5+5+4+5}=\frac{5}{24}=0,21 \\
& W C 2=\frac{5}{5+5+5+4+5}=\frac{5}{24}=0,21 \\
& W C 3=\frac{5}{5+5+5+4+5}=\frac{5}{24}=0,21 \\
& W C 4=\frac{4}{5+5+5+4+5}=\frac{4}{24}=0,17 \\
& W C 5=\frac{5}{5+5+5+4+5}=\frac{5}{24}=0,21
\end{aligned}
$$

Kemudian vektor $\mathrm{S}$ dihitung berdasarkan persamaan 1 .

Selin $=\left(90^{0,21}\right)\left(70^{0,21}\right)\left(70^{0,21}\right)\left(80^{0,17}\right)\left(90^{0,21}\right)=$ 82,943

Sesti $=\left(90^{0,21}\right)\left(90^{0,21}\right)\left(90^{0,21}\right)\left(80^{0,17}\right)\left(90^{0,21}\right)=$ 92,159

Saan $=\left(70^{0,21}\right)\left(70^{0,21}\right)\left(70^{0,21}\right)\left(70^{0,17}\right)\left(90^{0,21}\right)=$ 76,930

Sern $=\left(90^{0,21}\right)\left(60^{0,21}\right)\left(70^{0,21}\right)\left(70^{0,17}\right)\left(90^{0,21}\right)=$ 78,499

Syani $=\left(70^{0,21}\right)\left(100^{0,21}\right)\left(90^{0,21}\right)\left(80^{0,17}\right)\left(90^{0,21}\right)=$ 89,401

Sabdul $=\left(90^{0,21}\right)\left(80^{0,21}\right)\left(70^{0,21}\right)\left(80^{0,17}\right)\left(90^{0,21}\right)=$ 85,288 
Siis $=\left(90^{0,21}\right)\left(70^{0,21}\right)\left(90^{0,21}\right)\left(80^{0,17}\right)\left(70^{0,21}\right)=$ 82,943

Snunung $=\left(90^{0,21}\right)\left(90^{0,21}\right)\left(90^{0,21}\right)\left(80^{0,17}\right)\left(90^{0,21}\right)=$ 92,159

Sdahlan $=\left(90^{0,21}\right)\left(100^{0,21}\right)\left(90^{0,21}\right)\left(80^{0,17}\right)\left(90^{0,21}\right)=$ 94,238

Snani $=\left(90^{0,21}\right)\left(60^{0,21}\right)\left(70^{0,21}\right)\left(70^{0,17}\right)\left(90^{0,21}\right)=$ 78,499

Selanjutnya menentukan nilai vektor yang akan digunakan menghitung preferensi (Vi) untuk perangkingan dengan menggunakan persamaan 3 . Hasil perhitungan preferensi sebagai hasil perhitungan kelayakan kredit dapat dilihat pada tabel 6.

Tabel 6 Tabel Hasil Kelayakan Analis

\begin{tabular}{|l|l|l|l|}
\hline NO & \multicolumn{1}{|c|}{ NAMA } & NILAI V & $\begin{array}{l}\text { KELAYA } \\
\text { KAN }\end{array}$ \\
\hline 1 & Elin & 0,097 & Layak \\
\hline 2 & Esti Marisa Devi & 0,108 & Layak \\
\hline 3 & Aan Aminah & 0,090 & $\begin{array}{l}\text { Tidak } \\
\text { Layak }\end{array}$ \\
\hline 4 & Erna Hermawati & 0,092 & $\begin{array}{l}\text { Tidak } \\
\text { Layak }\end{array}$ \\
\hline 5 & Yani Suryani & 0,104 & Layak \\
\hline 6 & Abdul Aziz maulana & 0,099 & Layak \\
\hline 7 & Iis Siti Hoiriyah & 0,097 & Layak \\
\hline 8 & Nunung Nur Azizah & 0,108 & Layak \\
\hline 9 & Muhammad Dahlan & 0,110 & Layak \\
\hline 10 & Nani Heryani & 0,092 & $\begin{array}{l}\text { Tidak } \\
\text { Layak }\end{array}$ \\
\hline
\end{tabular}

Untuk kriteria nilai Kelayakan konsumen yaitu $\geq 0.095$ maka nilai kelayakan adalah layak. Sedangkan < 0.095 maka nilai kelayakan adalah tidak layak.

\subsection{Modelling Quick Plan \& Modelling Quick Design}

Pada tahap ini dilakukan perancangan aplikasi. Perancangan aplikasi dengan menggunakan pemodelan usecase diagram dapat dilihat pada gambar 4

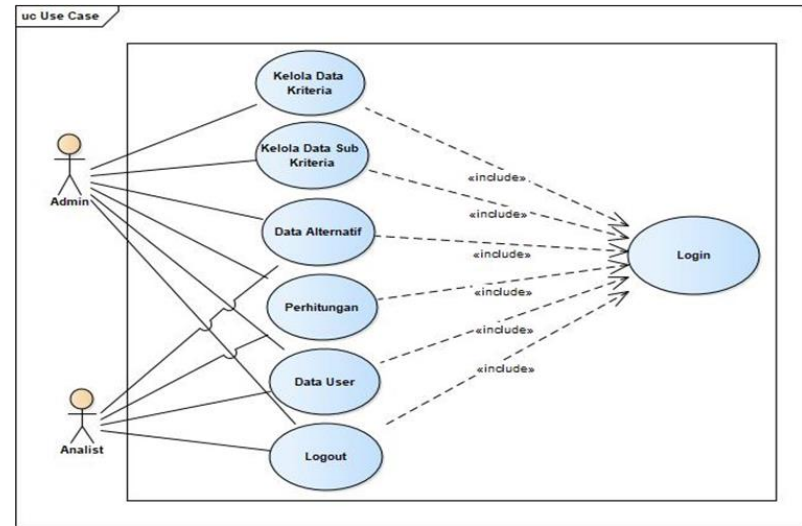

Gambar 4 Usecase Diagram

Rancangan halaman utama aplikasi dapat dilihat pada gambar 5 .

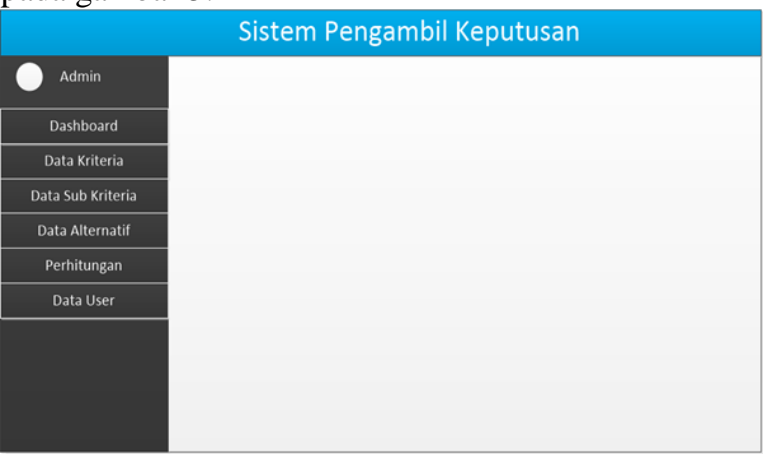

Gambar 5 Rancangan halaman Utama

Rancangan halaman data kriteria dapat dilihat pada gambar 6 .

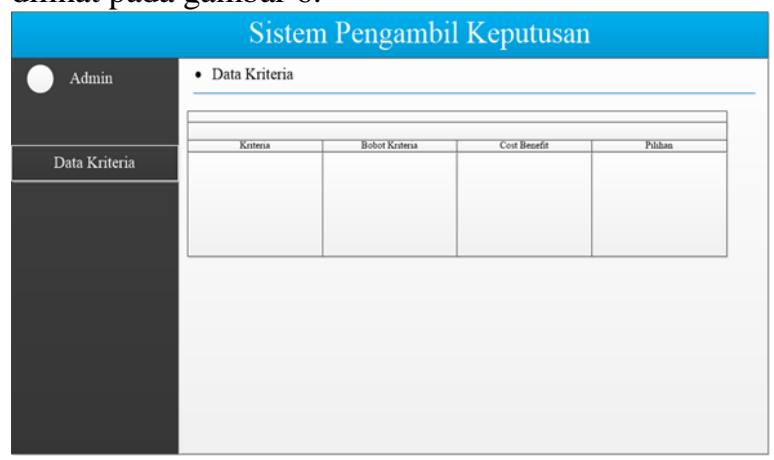

Gambar 6 Rancangan halaman data kriteria

\subsection{Construction of Prototype}

Setelah tahap perancangan, selanjutnya tahap pembangunan prototype sistem. Tampilan halaman utama dapat dilihat pada gambar 7 . 


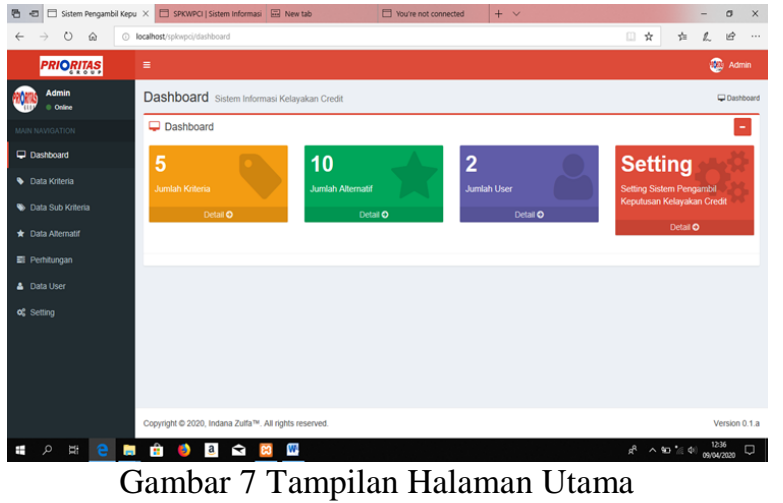

Tampilan halaman data kriteria dapat dilihat pada gambar 8 .

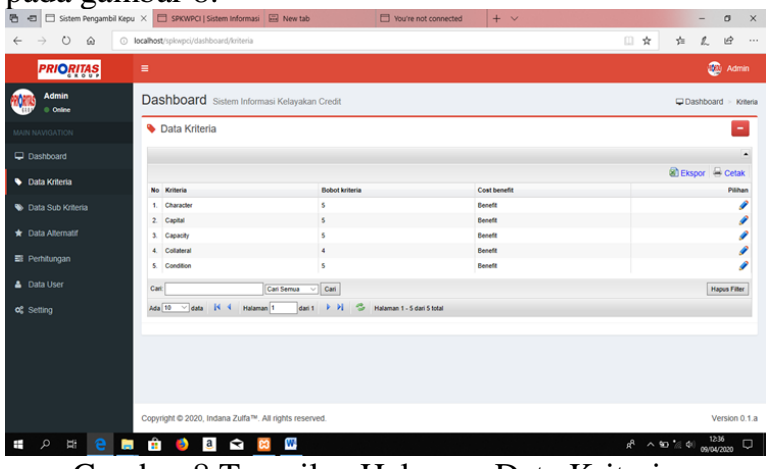

Gambar 8 Tampilan Halaman Data Kriteria

Tampilan halaman data sub kriteria dapat dilihat pada gambar 9 .

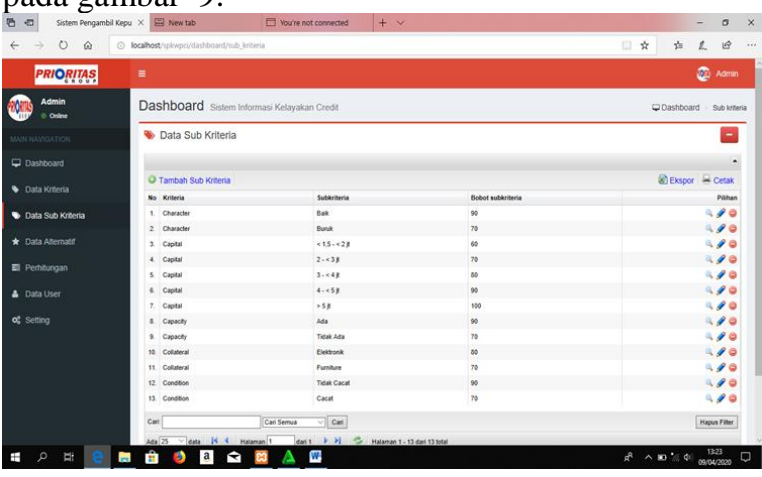

Gambar 9 Tampilan Halaman Data Subkriteria

Tampilan halaman data alternatif dapat dilihat pada gambar 10 .

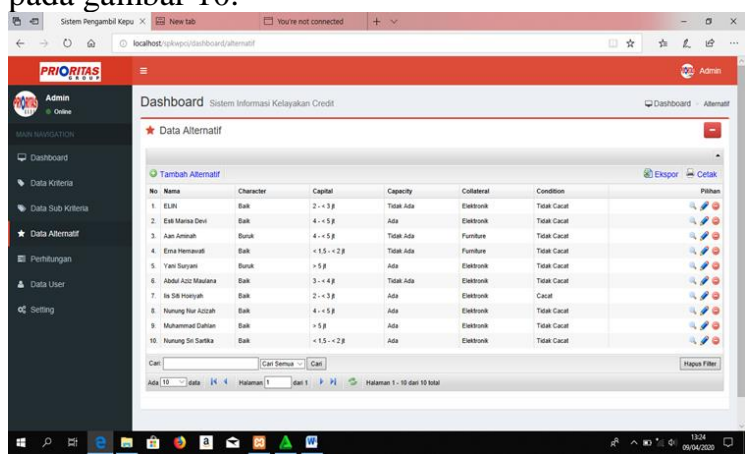

Gambar 10 Tampilan Halaman Data Alternatif
Tampilan halaman perhitungan dapat dilihat pada gambar 11 .

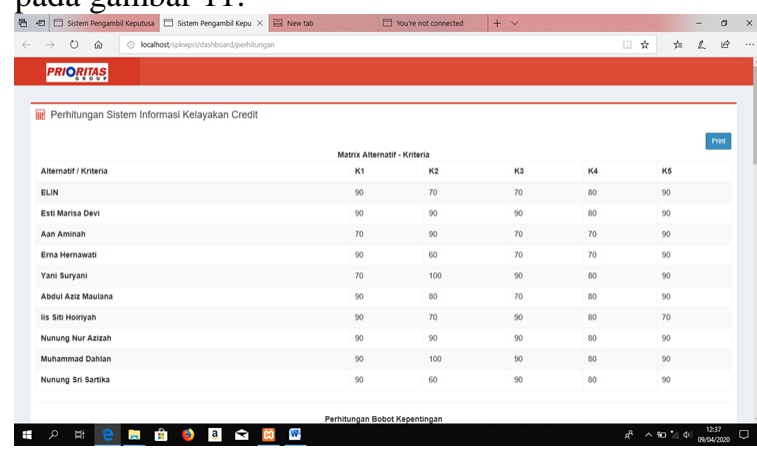

Gambar 11 Tampilan Halaman Perhitungan

Tampilan halaman hasil perhitungan dapat dilihat pada gambar 12 .

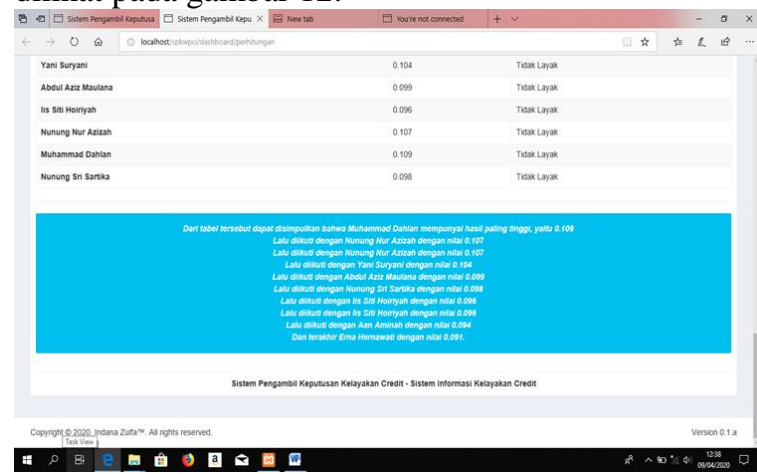

Gambar 12 Tampilan Halaman Hasil Perhitungan

\subsection{Deployment, Delivery and Feedback}

Pada fase ini perangkat lunak yang telah dibuat akan dipresentasikan kepada pengguna untuk dilakukan uji coba dan diperbaiki kembali bila terdapat kekurangan dalam perangkat lunak tersebut. Tabel pengujian aplikasi dapat dilihat pada table 6 .

Tabel 7 Pengujian Aplikasi

\begin{tabular}{|c|l|l|l|l|l|}
\hline $\begin{array}{c}\text { N } \\
\text { o }\end{array}$ & $\begin{array}{l}\text { Fungs } \\
\text { i yang } \\
\text { diuji }\end{array}$ & $\begin{array}{c}\text { Cara } \\
\text { penguji } \\
\text { an }\end{array}$ & $\begin{array}{c}\text { Hasil } \\
\text { yang } \\
\text { diharapk } \\
\text { an }\end{array}$ & $\begin{array}{l}\text { Keluara } \\
\text { n }\end{array}$ & Hasil \\
\hline 1 & Login & $\begin{array}{l}\text { Memas } \\
\text { ukan } \\
\text { userna } \\
\text { me dan } \\
\text { passwo } \\
\text { rd lalu } \\
\text { klik } \\
\text { tombol } \\
\text { login }\end{array}$ & $\begin{array}{l}\text { Menamp } \\
\text { ilkan } \\
\text { utaman } \\
\text { SPK }\end{array}$ & $\begin{array}{l}\text { Tampil } \\
\text { halama } \\
\text { nama }\end{array}$ & $\begin{array}{l}\text { Berh } \\
\text { asil }\end{array}$ \\
& $\begin{array}{l}\text { Utama } \\
\text { Klik } \\
\text { menu } \\
\text { Kriter } \\
\text { ia }\end{array}$ & $\begin{array}{l}\text { Menamp } \\
\text { ilkan } \\
\text { halaman } \\
\text { data } \\
\text { kriteria }\end{array}$ & $\begin{array}{l}\text { Tampil } \\
\text { halama } \\
\text { n data } \\
\text { kriteria }\end{array}$ & $\begin{array}{l}\text { Berh } \\
\text { asil }\end{array}$ \\
\hline 3 & $\begin{array}{l}\text { Menu } \\
\text { Data } \\
\text { Sub } \\
\text { Kriter }\end{array}$ & $\begin{array}{l}\text { Klik } \\
\text { menu }\end{array}$ & $\begin{array}{l}\text { Menamp } \\
\text { ilkan } \\
\text { halaman } \\
\text { data sub }\end{array}$ & $\begin{array}{l}\text { Tampil } \\
\text { halama } \\
\text { n sub } \\
\text { kriteria }\end{array}$ & $\begin{array}{l}\text { Berh } \\
\text { asil }\end{array}$ \\
\hline
\end{tabular}




\begin{tabular}{|c|c|c|c|c|c|}
\hline $\begin{array}{l}N \\
0\end{array}$ & $\begin{array}{l}\text { Fungs } \\
\text { i yang } \\
\text { diuji }\end{array}$ & $\begin{array}{c}\text { Cara } \\
\text { penguji } \\
\text { an }\end{array}$ & $\begin{array}{c}\text { Hasil } \\
\text { yang } \\
\text { diharapk } \\
\text { an }\end{array}$ & $\begin{array}{c}\text { Keluara } \\
\mathrm{n}\end{array}$ & Hasil \\
\hline & ia & & kriteria & & \\
\hline 4 & $\begin{array}{l}\text { Menu } \\
\text { Data } \\
\text { Altern } \\
\text { atif }\end{array}$ & $\begin{array}{l}\text { Klik } \\
\text { menu }\end{array}$ & $\begin{array}{l}\text { Menamp } \\
\text { ilkan } \\
\text { halaman } \\
\text { data } \\
\text { altenatif }\end{array}$ & $\begin{array}{l}\text { Tampil } \\
\text { halama } \\
\mathrm{n} \text { data } \\
\text { alternat } \\
\text { if }\end{array}$ & $\begin{array}{l}\text { Berh } \\
\text { asil }\end{array}$ \\
\hline 5 & $\begin{array}{l}\text { Tamb } \\
\text { ah } \\
\text { data }\end{array}$ & $\begin{array}{l}\text { Klik } \\
\text { tambah } \\
\text { data isi } \\
\text { form } \\
\text { tambah } \\
\text { data } \\
\text { dan klik } \\
\text { simpan }\end{array}$ & $\begin{array}{l}\text { Menamb } \\
\text { ah data } \\
\text { ke } \\
\text { database } \\
\text { dan } \\
\text { kembali } \\
\text { ke } \\
\text { halaman } \\
\text { data. }\end{array}$ & $\begin{array}{l}\text { Menam } \\
\text { bah } \\
\text { data }\end{array}$ & $\begin{array}{l}\text { Berh } \\
\text { asil }\end{array}$ \\
\hline 6 & Edit & $\begin{array}{l}\text { Meruba } \\
\text { h data } \\
\text { dan klik } \\
\text { simpan }\end{array}$ & $\begin{array}{l}\text { Melakuk } \\
\text { an } \\
\text { perubaha } \\
\text { n ke } \\
\text { database } \\
\text { dan } \\
\text { kembali } \\
\text { ke } \\
\text { halaman } \\
\text { data. }\end{array}$ & $\begin{array}{l}\text { Meruba } \\
\text { h data }\end{array}$ & $\begin{array}{l}\text { Berh } \\
\text { asil }\end{array}$ \\
\hline 7 & Hapus & $\begin{array}{l}\text { Mengh } \\
\text { apus } \\
\text { data } \\
\text { dan klik } \\
\text { ok }\end{array}$ & $\begin{array}{l}\text { Mengha } \\
\text { pus data } \\
\text { pada } \\
\text { database } \\
\text { dan } \\
\text { kembali } \\
\text { ke } \\
\text { halaman } \\
\text { data. } \\
\end{array}$ & $\begin{array}{l}\text { Mengh } \\
\text { apus } \\
\text { data }\end{array}$ & $\begin{array}{l}\text { Berh } \\
\text { asil }\end{array}$ \\
\hline 8 & $\begin{array}{l}\text { Menu } \\
\text { lapora } \\
\mathrm{n}\end{array}$ & $\begin{array}{l}\text { Klik } \\
\text { menu } \\
\text { perhitu } \\
\text { ngan }\end{array}$ & $\begin{array}{l}\text { Menamp } \\
\text { ilkan } \\
\text { hasil dan } \\
\text { proses } \\
\text { perhitun } \\
\text { gan } \\
\text { dengan } \\
\text { metode } \\
\text { WP }\end{array}$ & $\begin{array}{l}\text { Tampil } \\
\text { proses } \\
\text { perhitu } \\
\text { ngan }\end{array}$ & $\begin{array}{l}\text { Berh } \\
\text { asil }\end{array}$ \\
\hline 8 & $\begin{array}{l}\text { Cetak } \\
\text { lapora } \\
\mathrm{n}\end{array}$ & $\begin{array}{l}\text { Klik } \\
\text { menu } \\
\text { perhitu } \\
\text { ngan }\end{array}$ & $\begin{array}{l}\text { Menamp } \\
\text { ilkan } \\
\text { hasil dari } \\
\text { perhitun } \\
\text { gan dari } \\
\text { setiap } \\
\text { alternatif }\end{array}$ & $\begin{array}{l}\text { Tampil } \\
\text { hasil } \\
\text { perhitu } \\
\text { ngan } \\
\text { dalam } \\
\text { bentuk } \\
\text { pdf }\end{array}$ & $\begin{array}{l}\text { Berh } \\
\text { asil }\end{array}$ \\
\hline
\end{tabular}

\begin{tabular}{|l|l|l|l|l|l|}
\hline $\begin{array}{c}\text { N } \\
\text { o }\end{array}$ & $\begin{array}{l}\text { Fungs } \\
\text { i yang } \\
\text { diuji }\end{array}$ & $\begin{array}{c}\text { Cara } \\
\text { penguji } \\
\text { an }\end{array}$ & $\begin{array}{c}\text { Hasil } \\
\text { yang } \\
\text { diharapk } \\
\text { an }\end{array}$ & $\begin{array}{c}\text { Keluara } \\
\mathrm{n}\end{array}$ & Hasil \\
\hline 9 & $\begin{array}{l}\text { Logo } \\
\text { ut }\end{array}$ & $\begin{array}{l}\text { Klik } \\
\text { logout }\end{array}$ & $\begin{array}{l}\text { Keluar } \\
\text { dari } \\
\text { sistem }\end{array}$ & $\begin{array}{l}\text { Tampil } \\
\text { ke } \\
\text { halama } \\
\text { n login }\end{array}$ & $\begin{array}{l}\text { Berh } \\
\text { asil }\end{array}$ \\
\end{tabular}

\section{Kesimpulan dan Saran}

Sistem pendukung keputusan kelayakan pengajuan kredit di Prioritas Group Purwakarta dengan menggunakan metode Weighted Product (WP) telah selesai dibuat dengan menggunakan metode pengembangan perangkat lunak Prototye Pressman 2010 dan perancangan model menggunakan Unified Modeling Language (UML), sistem dibangun dengan bahasa pemrograman PHP dan database MySQL, serta pengujian sistem menggunakan metode black box.

Didalam sistem terdapat beberapa fitur utama seperti fitur data kriteria, data sub kriteria yang dilengkapi dengan tambah data dan ubah data, fitur data alternatif untuk melakukan penyeleksian calon konsumen dengan perhitungan metode Weighted Product (WP) dan fitur perhitungan untuk menampilkan hasil perhitungan dari seluruh calon konsumen atau alternatif.

Dengan dibuatnya Sistem Pendukung Keputusan kelayakan pengajuan kredit di Prioritas Group Purwakarta untuk menentukan kelayakan calon konsumen yang akan diberi kredit dapat memudahan bagi analis dalam memberikan alternatif keputusan dalam memilih peserta calon konsumen dilengkapi nilai prioritas dengan mengacu kepada kriteria-kriteria pengambilan keputusan yang telah ditetapkan.

Untuk pengembangan selanjutnya penulis menyarankan agar sistem ini dapat diaplikasikan secara online sehingga para pengambil keputusan bisa melihat hasil dari sistem ini di manapun dia berada.

\section{Daftar Pustaka:}

Jalil, Abdul, Ningrum, Ika Purwati, Muchtar, Mutmainah. 2017. Spk Pemberian Kredit Menggunakan Metode WP (Weighted Product) Pada Bmt Mu'amalah Sejahtera Kendari. Semantik vol.3 No.1 Jan-un 2017, pp.173-180, ISSN:2502-8928. Universitas Halu Oleo Kendari.

Kusumadewi, Sri, Hari Purnomo, Hari. 2010. Aplikasi Logika Fuzzy untuk Pendukung Keputusan. Yogyakarta : Graha Ilmu.

Pressman, Roger S., P. D. 2010. Software Engineering A Practitioner's Approach 7th 
Edition. (McGraw-Hill, Ed.). New York: Raghothaman Srinivasan

Sari, Febrina. 2017. Metode dalam pengambilan keputusan. Yogyakarta: Deepublish.

Wibowo. 2011. Perancangan Sistem Pendukung Keputusan. Depok. 